\title{
FAKTOR-FAKTOR PENENTU ADOPSI E-WALLET OVO DI PROVINSI JAWA TIMUR
}

\author{
Chowal Jundy Kumoro1, * \\ Magister Manajemen, Universitas Hayam Wuruk Perbanas, Surabaya, Indonesia, \\ junchowal@gmail.com \\ *Corresponding author \\ Basuki Rachmat ${ }^{2}$ \\ Magister Manajemen, Universitas Hayam Wuruk Perbanas, Surabaya, Indonesia, \\ basuki@perbanas.ac.id
}

\begin{abstract}
Background - For several years the existence of the internet and smartphones has changed the lives of the wider community by making an important role in the development of digital technology. One of them is the development of innovation in the field of financial services. Electronic wallet (E-wallet) or digital wallet is part of financial technology that provides !

Diterima : 03 Juli 2021

Direview : 03 Agustus 2021

Direvisi : 15 Desember 2021

Disetujui : 31 Januari 2022 services or features in financial payment methods that utilize internet services. People can transact faster by utilizing digital payment methods.

Purpose - Determine and analyze the effect of perceived usefulness variable, relative advantage variable, social influence variable, risk perception variable, cost variable on behavioural intention. Test and analyze the effect of behavioural intention on consumer adoption of OVO in East Java Province.

Design/ Methodology/ Approach - This study used a sample of 130 respondents using questionnaires distributed to respondents online using Google forms. The data processing method used in this research is Partial Least Square (PLS) with WarpPLS 6.0 software. The sample in this study is OVO users who live in East Java Province. The type of sampling in this research is purposive sampling.

Results and Discussion-Perceived usefulness and relative advantages have a significant and positive effect on behavioural intention. Social influence, perceived risk and cost have no impact on behavioural intention. behavioural intention has a significant positive effect on OVO adoption.

Conclusion - OVO users are presented with the many features and conveniences offered. In research, users use this service because these users feel benefits such as being able to make transactions faster and feel more comfortable than cash payments. In addition, the decision to use OVO services is not influenced by social influences, perceived risk and cost.

Research implications - Expanding collaboration with new merchants and adding new features to make it easier to use and improve the performance of service users. Enriching features that users can take advantage of in managing and controlling their finances. The need for a reward program for service users who recommend OVO. OVO needs to provide certainty to users that OVO services are safe from possible risks such as malfunctions and privacy security.

Research limitations - This study involving 130 respondents was undertaken with the sample of user of OVO in east java province and sample may not be a representation of the population. In this study only limited to the variables of Perceived usefulness, Relative Advantage, Social Influence, Perceived Risk, Cost, Behavioural Intention and OVO Adoption.
\end{abstract}

Keywords - Advantage, Social, Influence, Risk, Cost, Adoption 


\begin{abstract}
Abstrak
Latar Belakang - Selama beberapa tahun keberadaan internet dan smartphone merubah kehidupan masyarakat luas dengan memerankan peran penting sebagai pembangunan teknologi digital. Salah satunya adalah perkembangan inovasi di bidang jasa keuangan. Electronic wallet (E-wallet) atau dompet digital merupakan bagian dari finnancial technology yang menyuguhkan layanan atau fitur di metode pembayaran keuangan yang memanfaatkan layanan internet. Masyarakat dapat bertransaksi lebih cepat dengan memanfaatkkan metode pembayaran digital.

Tujuan - Menguji dan menganalisis pengaruh variabel manfaat yang dirasakan, variabel keunggulan relatif, variabel pengaruh sosial, variabel persepsi risiko, variabel biaya terhadap niat mengadopsi dan Menguji dan menganalisis pengaruh niat mengadopsi terhadap adopsi konsumen pada OVO di Provinsi Jawa Timur.

Desain/ Metodologi/ Pendekatan - Penelitian ini menggunakan sampel sebanyak 130 responden menggunakan kuesioner disebarkan kepada responden secara online menggunakan Google forms. Metode pengolahan data yang digunakan dalam penelitian ini adalah Partial Least Square (PLS) dengan software WarpPLS 6.0. Sampel dalam penelitian ini adalah pengguna OVO yang berdomisili di Provinsi Jawa Timur. Jenis pengambilan sampel dalam penelitian ini purposive sampling.

Hasil dan Pembahasan- Manfaat yang dirasakan dan keunggulan relatif berpengaruh signifikan positif terhadap niat mengadopsi. Pengaruh sosial, persepsi risiko dan biaya tidak berdampak pada niat mengadopsi. Niat mengadopsi berpengaruh signifikan positif terhadap adopsi OVO.

Kesimpulan - Pengguna OVO disuguhkan dengan banyaknya fitur dan kemudahan yang ditawarkan. Pada penelitian pengguna menggunakan layanan ini dikarenakan pengguna tersebut merasakan manfaat seperti dapat melakukan transaksi yang lebih cepat dan merasa lebih nyaman dibanding pembayaran tunai. Selain itu keputusan untuk menggunakan layanan OVO tidak dipengaruhi oleh pengaruh sosial, persepsi risiko dan biaya.

Implikasi penelitian - Memperluas kerja sama dengan merchant baru dan menambah fitur-fitur baru agar dapat digunakan lebih mudah digunakan dan dapat meningkatkan kinerja pengguna layanan. Memperkaya fitur yang dapat dimanfaatkan pengguna dalam mengelola dan mengontrol keuangannya. Perlunya adanya program pemberian reward bagi pengguna layanan yang merekomendasikan OVO. OVO perlu memberikan kepastian kepada pengguna bahwa layanan OVO aman dari kemungkinan terjadinya risiko-risiko seperti kesalahan fungsi dan keamanan privasi.

Batasan penelitian - Penelitian ini melibatkan sebanyak 130 responden dengan sampel pengguna OVO di Provinsi Jawa Timur dan kemungkinan sampel tidak dapat mewakili populasi atau tidak dapat menggambarkan kondisi lapangan sesungguhnya. Dalam penelitian ini hanya terbatas pada variabel Manfaat yang Dirasakan, Keunggulan Relatif, Pengaruh Sosial, Persepsi Risiko, Biaya, Niat Mengadopsi dan Adopsi OVO.
\end{abstract}

Kata Kunci - Keunggulan, Pengaruh, Sosial, Risiko, Biaya, Adopsi

\section{PENDAHULUAN}

Perkembangan teknologi dalam masyarakat modern saat ini mengharuskan semua sektor bisnis untuk terus berinovasi. Selama bertahun-tahun keberadaan smartphone merubah kehidupan masyarakat secara luas dengan memegang peran penting sebagai media pembangunan teknologi digital. Masyarakat disuguhkan banyaknya pilihan dalam melakukan transaksi keuangan dengan cepat dan mudah dalam metode pembayaran berbasis digital. Perubahan ini juga berdampak pada perilaku konsumen, yaitu pergeseran pola 
pembelian yang dilakukan dari penjualan manual ke penjualan online (Halttunen, 2016). Mobile Payment merupakan segala layanan pembayaran yang dilakukan melalui perangkat seluler. Ada beberapa jenis layanan mobile payment yang tersedia baik sebagai remote atau pembayaran jarak jauh maupun pembayaran fisik, Pembayaran fisik dapat menggunakan teknologi NFC (near-field communication) seperti transaksi menggunakan kartu kredit/ debit dari bank, atau teknologi layanan pembayarn yang menggunakan keduanya yaitu remote dan pembayaran fisik seperti E-wallet dan kode $Q R$ (Punwatkar \& Verghese, 2018). Pengertian $e^{-}$ wallet dari Bank Indonesia berdasar Peraturan Bank Indonesia (PBI) Nomor. 18/40/PBI/2016 tentang penyelenggaraan transaksi pembayaran, yaitu sebuah layanan elektronik untuk menyimpan data instrumen pembayaran antara lain alat pembayaran dengan menggunakan kartu/dan/atau yang dapat juga menampung dana, untuk melakukan pembayaran.

Terdapat pertumbuhan pesat penggunaan $e$-wallet di Indonesia, menurut survey dari Nielsen Digital Consumer 2019 dalam 2 tahun terakhir 98\% smartphone digunakan untuk mengakses internet. 67\% dari pengguna internet tersebut rata-rata menghabiskan Rp 50.00 sd Rp 500.000 yang mayoritas digunakan untuk berbelanja online. Adanya tren belanja online maka metode pembayaran saat ini mulai bergeser menjadi pembayaran digital atau e-wallet. Sebanyak $56 \%$ pengguna internet telah menggunakan layanan e-wallet hampir setiap harinya, $81 \%$ digunakan untuk membayar makanan \& minuman, 72\% pengguna menggunakan layanan $e$-wallet untuk pembayaran transportasi dan 41\% diantaranya digunakan untuk membayar tagihan.

Tumbuh pesatnya pembayaran digital di Indonesia sejalan dengan meningkatnya pengguna internet tiap tahunnya. Menurut hasil survey dari Asosiasi penyelenggara jasa internet Indonesia (APJII) pada tahun 2020 pengguna internet di Indonesia naik menjadi 196,7 juta atau setara dengan 73,7 persen dari populasi penduduk. Menurut survei dari iprice.co.id pada bulan Juni 2020 jumlah pengguna $e$-wallet di Indonesia adalah sebanyak 2,83 Miliar. Menurut data Bank Indonesia per 27 Mei 2020 terdapat 50 penyelenggara uang elektronik yang telah memperoleh izin dari Bank Indonesia dan 5 peringkat pertama penyedia layanan dompet digital yang sudah dikenal dengan luas oleh masyarakat pada yaitu Go-Pay, OVO, DANA, LinkAja, dan Jenius.

OVO merupakan layanan uang elektronik yang didirikan oleh Lippo Group dan dimiliki PT Visionet Internasional dan sudah terdaftar di Bank Indonesia sejak 22 Agustus 2017. Layanan keungan digital ini 
sudah termasuk unicorn karena pada Oktober 2019 OVO bernilai sekitar $\$ 2,9$ miliar. Berdasarkan survey dari iprice.co.id yang bekerja sama dengan AppAnie pada Q2 2020 meneliti 10 aplikasi $e$-wallet terbesar di Indonesia berdasarkan jumlah pengguna aktif bulanan. Pada riset tersebut lima peringkat teratas yaitu Go-Pay pada urutan pertama, OVO di posisi kedua, diikuti oleh DANA peringkat ketiga, LinkAja peringkat keempat dan Go Mobile dari CIMB Niaga menempati urutan kelima. Peringkat pengguna OVO terus meningkat sejak Q2 2017, selain itu OVO menduduki peringkat kedua berdasarkan jumlah download aplikasi dan jumlah pengguna bulanan di pada tahun 2019 sampai dengam 2021. Menunjukan hasil bahwa ShopeePay merupakan layanan e-wallet dengan pengguna terbanyak yaitu (68\%) sedangkan pengguna OVO sebanyak (56\%), GoPay (56\%), Dana (42\%) dan LinkAja sebanyak (19\%). Pangsa pasar transaksi terbesar $e^{-}$ wallet di Indonesia juga di pimpin oleh ShopeePay sebanyak 32\% dati total jumlah transaksi e-wallet, OVO sebesar 25\%, GoPay sebanyak 20\% Dana sebanyak 16\% dan LinkAja sebanyak 8\% \% dati total jumlah transaksi ewallet di Indonesia. Dilihat dari hasil survei tersebut menunjukan bahwa OVO masih sedikit tertinggal dari dua kompetitor potensialnya yaitu GoPay dan ShopeePay.
Perkembangan dari layanan OVO juga cenderung tidak signifikan tiap tahunnya, yang tampaknya dapat disebabkan oleh faktor tingginya persaingan dan banyaknya kompetitor dengan layanan serupa yang menawarkan atau memiliki keunggulan lain, baik dari segi promosi, fitur-fitur tambahan dan penawaran menarik lainnya. Banyaknya pilihan metode pembayaran digital yang ada dan diimbangi oleh tingginya jumlah pengguna smartphone, masih sangat banyak orang yang lebih memilih untuk menggunakan metode pembayaran langsung baik tunai dan metode pembayaran langsung lain seperti menggunakan kartu debit maupun kartu kredit.

Adanya faktor pendorong yang didapat oleh pengguna layanan berupa kemudahaan dan keuntungan yang didapat maka diangkatlah beberapa variabel berdasarkan penelitian terdahulu yaitu manfaat yang dirasakan, keunggulan relatif dan pengaruh sosial. Adanya faktor penghambat adopsi $e$-wallet yang berupa kekhawatiran para pengguna akan risikorisiko yang mungkin akan didapatkanya maka variabel yang diangkat yaitu persepsi risiko dan biaya yang mempengaruhi niat mengadopsi layanan e-wallet OVO.

Dalam beberapa penelitian yang telah di lakukan di berbagai negara di dunia untuk yang juga meneliti tentang teori adopsi teknologi terdapat sangat banyak perbedaan 
ada faktor yang mempengaruhi maupun tidak mempengaruhi. Dalam penelitian terdahulu yang dilakukan Madan \& Yadav (2016). Hongxia et al., 2011 tidak terdapat variabel perceived usefulness atau manfaat yang dirasakan dimana variabel tersebut merupakan salah satu variabel utama dari konsep TAM (Technology Acceptance Model) oleh Davis pada tahun 1986. Sehingga secara teori penelitian ini perlu dilakukan guna memperluas penelitian sejenis.

\section{TINJAUAN PUSTAKA}

\section{Adopsi OVO}

Adopsi OVO merupakan keputusan untuk menggunakan atau memanfaatkan secara penuh layanan e-wallet OVO oleh konsumen sesuai dengan kesadaran dan sikapnya terhadap stimulus untuk menggunakan layanan tersebut. Electronic wallet (E-wallet) atau dompet digital merupakan bagian dari finnancial technology yang menyuguhkan layanan atau fitur di metode pembayaran keuangan yang memanfaatkan layanan internet. Layanan ini dapat dikatakan juga sebaga pengganti uang tunai.

Pengertian E-Wallet berdasar Peraturan Bank Indonesia No. 18/40/PBI/2016 tentang penyelenggaraan pemrosesan transaksi pembayaran, yaitu layanan elektronik untuk menyimpan data instrumen pembayaran antara lain alat pembayaran dengan menggunakan kartu/dan/atau yang dapat juga menampung dana, untuk melakukan pembayaran. Menurut Kotler dan Amstrong (2008) proses adopsi merupakan sebuah proses mental yang harus dilalui seseorang mulai dari ketika pertama kali mendengar tentang sebuah inovasi baru sampai dengan adopsi akhir, selain itu adopsi merupakan bagian dari tahap-tahap proses yaitu:

a) Kesadaran adalah sebuah fase konsumen menyadari adanya sebuah produk atau inovasi baru tetapi masih kekurangan informasi tentang produk tersebut atau informasi yang didapatkan konsumen tersebut masih sangat minim.

b) Minat merupakan tahap dimana konsumen mencari informasi lebih banyak tentang produk atau inovasi baru tersebut, dan pada tahap ini konsumen mulai menaruh minat terhadap produk baru tersebut.

c) Evaluasi merupakan fase dimana konsumen mulai mempertimbangkan dan menilai dari informasi-informasi yang didapatnya apakah harus untuk mencoba produk baru itu merupakan keputusan yang bagus.

d) Mencoba yaitu fase dimana konsumen mencoba produk baru dalam skala kecil untuk menentukan apakah produk itu sesuai dengan keinginanya.

e) Adopsi adakah keputusan konsumen untuk terus memakai produk baru tersebut secara penuh. 
Alalwan et al., 2016 adopsi adalah sebuah keputusan untuk menggunakan sebuah inovasi secara penuh, dimana menggunakan inovasi merupakan keputusan terbaik. Selain itu adopsi dapat di definisikan sebagai perilaku baru seseorang sesuai dengan latar belakang, pengetahuan, kesadaran, dan sikapnya terhadap rangsangan.

\section{Manfaat yang Dirasakan}

Manfaat yang dirasakan merupakan teori dari Davis (1989) sebagai anteseden dari adopsi individu terhadap teknologi informasi baru atau tentang Technology acceptance model (TAM) yang sudah di kembangkan ke banyak penelitian. Manfaat yang dirasakan merupakan sejauh mana seseorang menggunakan suatu sistem akan meningkatkan kinerja akan pekerjaannya, dan sistem ini akan cenderung berhasil jika menarik dan juga memenuhi ekspektasi individu tentang penerapan sistem ini pada penggunaan sesungguhnya Phuah et al (2018). Menurut Madan dan Yadav, (2016) manfaat yang merupakan tingkat dimana konsumen percaya bahwa menggunakan layanan mobile payment membantu meningkatkan kinerjanya.

\section{Keunggulan Relatif}

Keunggulan relatif mengacu pada sejauh mana penggunaan teknologi baru dianggap sebagai pilihan lebih baik daripada menggunakan teknologi sebelumnya
Makanyeza, 2017). Menurut Shaikh \& Karjaluoto (2015) keunggulan relatif digambarkan sebagai tingkat di mana seseorang memandang sebuah inovasi sebagai keuntungan yang ditawarkan lebih baik dari sistem sebelumnya yang digunakan untuk melakukan tugas yang sama. Menurut Tatik Suryani (2012) suatu produk akan mudah diterima oleh konsumen jika produk terebut memiliki keunggulan relatif atau memiliki keunggulan jika dibandingkan produk atau layana yang sudah ada sebelumnya di pasar. Keunggulan relatif adalah sebuah inovasi yang berhubungan positif dengan adopsi dari sebuah teknologi.

\section{Pengaruh Sosial}

Pengaruh sosial atau social influence didefinisikan sebagai keputusan konsumen untuk menggunakan suatu produk atau layanan karena mendapatkan pengaruh atau opini dari orang-orang dekatnya seperti keluarga, rekan kerja, (Dastan \& Gurler, 2016). Makanyeza, (2017) menunjukan bahwa pengaruh social mengacu pada tekanan yang diberikan kepada seseorang oleh orang lain yang sudah mengadopsi inovasi tertentu, termasuk anggota keluarga, teman, rekan kerja atau anggota lain yang termasuk dalam kelompok yang sama dengan individu tersebut dan interaksi dianggap penting karena mengatur cara orang berperilaku yang sesuai. 
Menurut Phuah et al., 2010 social influence adalah sejauh mana pengguna individu mendapatkan saran tentang pentingnya penggunakan inovasi. Saat ada teknologi/ layanan baru muncul ini membuat individu tersebut masih ragu untuk menggunakannya dan akan berinteraksi kepada orang yang sudah menggunaknya sebelum membuat keputusan. Pengaruh sosial merupakan sekelompok individu dekat saling yang mempertimbangkan persamaan di dalam status atau penghargaan, komunitas tersebut saling bersosialisasi diantara individu-individu tersebut baik secara formal dan non formal (Schiffman dan Kanuk, 2008).

Perilaku konsumen juga dipengaruhi oleh faktor-faktor sosial yang termasuk didalamnya berupa kelompok kecil, keluarga, serta peran dan status sosial konsumen (Kotler dan Amstrong, 2008). Pengaruh sosial dapat diartikan juga sebagai sebagai hal penting yang mempengaruhi individu dalam menggunakan produk $e$-wallet atau dalam penerimaan teknologi baru.

\section{Niat Mengadopsi}

Perilaku adalah evaluasi, perasaan dan kecenderungan seseorang yang relatif konsisten terhadap suatu objek dan gagasan. Perilaku menempatkan seseorang kedalam satu pikiran menyukai atau tidak menyukai obyek dan ide tertentu hal ini bahkan dapat bergerak mendekati atau menjauhi sesuatu. Menurut Tatik Suryani (2012) behavior intention dijelaskan juga sebagai komponen sikap konatif yaitu predisposisi atau kecenderungan konsumen untuk melakukan suatu tindakan berkenaan dengan obyek sikap, selain itu behavior intention merupakan satu dari tiga model komponen sikap yaitu yaitu affective, behavior intention dan cognitive dan behavior intention bukan merupakan tindakan tetapi masih dalam tahap keinginan atau intensi untuk menggunakan suatu layanan terknologi atau produk baru. Peran faktor perilaku merupakan suatu hal yang sangat penting bagi seorang pengguna yang hendak memakai suatu layanan. Menurut De Sena et al., 2016 behavioral intention adalah niat penggunaan yang efektif oleh konsumen produk atau layanan tersebut di masa depan. Menurut Madan \& Yadav 2016) niat mengadopsi mengacu pada ukuran atau tingkat intensitas niat individu untuk melakukan sebuah perilaku spesifik.

\section{Persepsi risiko}

Persepsi Risiko merupakan segala risiko yang terkait dengan keuangan, sosial dan produk yang dirasakan konsumen terhadap transaksi online (Madan \& Yadav 2016). Menurut De Sena Abrahão et al., 2016 persepsi risiko didefinisikan sebagai tingkat dimana konsumen pengguna layanan mobile payment percaya akan adanya kemungkinan terkena risiko keuangan, 
social, psikologis, fisik dan waktu. Menurut Tatik Suryani (2012) persepsi risiko merupakan sebuah ketidakpastian yang dihadapi konsumen ketika tidak dapat melihan kemumngkinan yang akan terjadi dari keputusan pembelian yang dilakukan, selain itu persepsi risiko digolongkan menjadi enam jenis risiko yaitu:

1. Risiko keuangan merupakan risiko yang dampak kerugian yang didapat konsumen dari segi finansial.

2. Risiko kinerja Merupakan risiko yang didapat konsumen jika produk tidak memberikan kinerja sesua dengan harapan konsumen.

3. Risiko psikologis merupakan dampak dari risiko yang di dapat konsumen adalah sesuatu perasaan ketidaknyaman, citra diri menjadi buruk dan harga diri menjad rendah yang didapat oleh konsumen setelah menggunakan suatu produk.

4. Risiko fisiologis merupakan risiko fisik yang mungkin didapat konsumen setelah menggunakan suatu produk.

5. Risiko sosial adalah dampak sosial yang didapat konsumen berupa kurang di terimanya di lingkungan sosial akibat membeli atau menggunakan suatu produk.

6. Risiko waktu adalah sebuah risiko berupa tersitanya waktu konsumen akibat menggunakan suatu produk.
Dalam penelitian ini, risiko yang didefinisikan sebagai persepsi terhadap risiko keamanan atau privasi, risiko keuangan, social risiko dan risiko waktu.

\section{Hipotesis}

Pengguna merasa menggunakan layanan $e$ wallet memberikan manfaat baginya maka semakin tinggi nilai manfaat yang dirasakan terhadap niat mengadopsi. Nilai manfaat yang dirasakan akan rendah terhadap niat mengadopsi jika konsumen tersebut dalam menggunakan layanan ini merasa tidak mendapatkan manfaat yang sesuai ekspektasi pengguna tersebut. Menurut hasil penelitian dari Bashir \& Madhavaiah (2015) menunjukan manfaat yang dirasakan berpengaruh positif terhadap niat mengadopsi. Hasil penelitian dari Alalwan et al., (2016) menunjukan manfaat yang dirasakan berpengaruh signifikan terhadap niat mengadopsi.

H1: Manfaat yang dirasakan berpengaruh signifikan positif terhadap niat mengadopsi pada OVO.

Wang \& Dai, (2020) menunjukan keunggulan relatif berpengaruh positif terhadap niat mengadopsi dan semakin banyak konsumen memandang teknologi baru lebih baik daripada teknologi yang digunakan sebelumnya, semakin besar kemungkinan untuk menerima inovasi. Menurut Schiffman \& Kanuk, (2008) perilaku pengguna berpengaruh positif terhadap niat mengadopsi. Individu tersebut 
lebih merasa nyaman menggunakan inovasi layanan ini dan layanan ini dianggap dapat menjadikan lebih efisien saat digunakan oleh individu tersebut maka nilai keunggulan relatif terhadap niat mengadopsi akan semakin tinggi.

H2: Keunggulan relatif berpengaruh signifikan positif terhadap niat mengadopsi pada OVO.

Pengaruh sosial juga dikenal sebagai norma sosial, hal ini mengacu pada sejauh mana individu percaya bahwa seorang individu akan menyetujui perilaku tertentu atau norma yang mengacu pada tekanan yang diberikan pada individu oleh orang disekitarnya. Berdasarkan penelitian oleh Hongxia et al., 2011 pengaruh sosial berpengaruh signifikan terhadap niat mengadopsi. Penelitian oleh Wang dan Dai, (2020) juga mendukung pernyataan tersebut dimana pengaruh social berpengaruh signifikan terhadap niat mengadopsi dalam adopsi mobile payment di Tiongkok. Hasil penelitian dari De Sena et al., 2016 juga sejalan dengan penelitian ini dimana pengaruh sosial berpengaruh signifikan positif terhadap niat mengadopsi mobile payment. Pengaruh ini biasanya didapat dari pengaruh sosial baik keluarga, rekan kerja dan kelompok sosial lainya, hal ini tentunya dapat juga berpengaruh terhadap perilaku individu. Rekomendasi orang terdekat dan pengaruh positif maupun negatif juga sangat mempengaruhi tinggi rendahnya nilai pengaruh sosial terhadap niat mengadopsi.

H3: Pengaruh sosial berpengaruh signifikan positif terhadap niat mengadopsi pada OVO. Persepsi risiko merupakan ketidakpastian yang mungkin dimiliki pelanggan saat melakukan pembayaran melalui ponsel. Hasil penelitian dari De Sena et al., 2016 menunjukan bahwa persepsi risiko berpengaruh negative dan signifikan terhadap niat mengadopsi. Penelitian dari Hongxia et al., 2011 menyatakan bahwa persepsi risiko berpengaruh negative terhadap niat mengadopsi untuk mengadopsi mobile payment. Semakin tinggi risiko maka niat mengadopsi dari konsumen untuk terus memakai e-wallet semakin kecil dan begitupun sebaliknya, jika pengguna merasa risiko dalam penggunaan layanan ini kecil maka orang tersebut akan terus menggunakan layanan ini. Kekhawatiran tentang keamanan privasi, dan data penting sangat mempengaruhi persepsi pengguna dalam penelitian ini. Penelitian dari Hongxia et al., 2011 mengatakan bahwa persepsi risiko merupakan faktor penghambat utama dalam adopsi mobile payment.

H4: Persepsi risiko berpengaruh signifikan negatif terhadap niat mengadopsi pada OVO.

Biaya merupakan faktor yang sangat dipertimbangkan oleh pengguna e-wallet. Biaya yang tinggi akan menjadi hambatan bagi dalam mempengaruhi sikap perilaku 
pengguna layanan. Saat konsumen berniat memutuskan untuk menggunakan atau tidak layanan e-wallet konsumen tersebut akan melakukan evaluasi atau mempertimbangkan biaya dan manfaat yang dikeluarkan dan yang didapatnya. Penelitian dari Hongxia et al., 2011 menyatakan bahwa biaya berpengaruh negative terhadap niat mengadopsi pada adopsi mobile payment.

H5: Biaya berpengaruh signifikan negatif terhadap niat mengadopsi pada OVO.
Niat mengadopsi didefinisikan sebagai perasaan positif atau negatif seorang pengguna e-wallet terhadap niatnya dalam memakai layanan OVO terlepas dari perilaku dan kecenderungan individu. Hasil penelitian dari Hongxia et al., 2011 menyatakan bahwa niat mengadopsi berpengaruh positif terhadap adopsi mobile payment.

H6: Niat mengadopsi berpengaruh signifikan positif terhadap adopsi OVO.

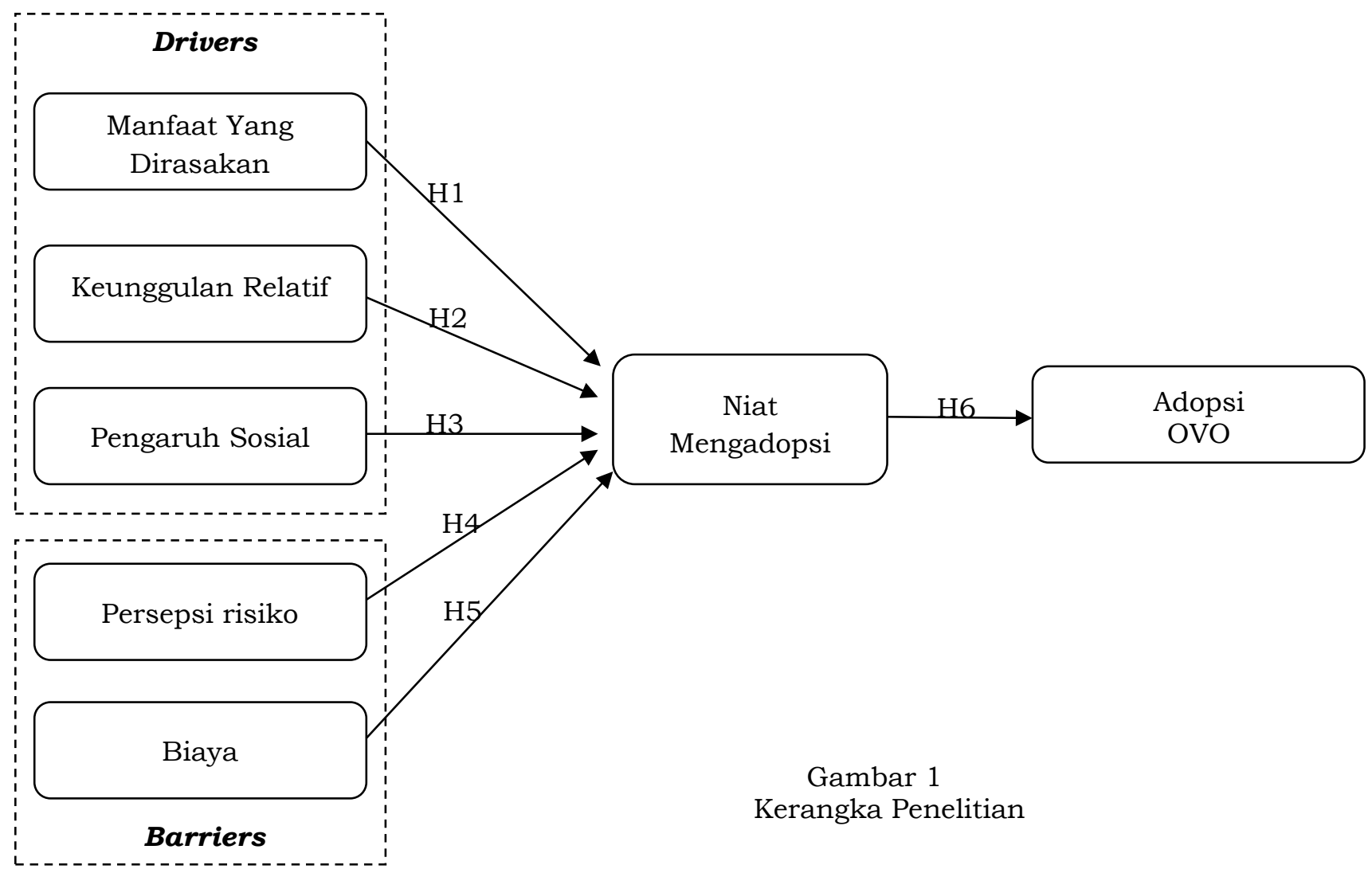

\section{METODOLOGI PENELITIAN}

Penelitian ini menggunakan metode penelitian kuantitatif kausal. Menurut Kuncoro (2013) pendekatan kuantitatif kausal merupakan pendekatan dalam penelitian yang mencari hubungan antar satu variabel dengan variabel lain yang memiliki hubungan sebab akibat. Penelitian 
ini bertujuan untuk mengetahui dan menganalisis faktor pendorong dan penghambat terhadap penggunaan electronic wallet

Populasi adalah semua kumpulan elemen yang menunjukkan ciri-ciri yang dapat digunakan dalam hal menarik kesimpulan. (Kuncoro, 2013). Populasi yang digunakan untuk penelitian saat ini adalah pengguna e-wallet di OVO di Jawa Timur.

Menurut Kuncoro (2013) sampel merupakan bagian dari jumlah karakteristik yang ada pada populasi. Sampel dalam penelitian ini sejumlah 130 responden yang merupakan pengguna $e$-wallet OVO yang ada di Jawa Timur. Penentuan jumlah sampel dalam penelitian ini adalah sebanyak 130 sampel dianggap sudah mencukupi dengan menggunakan model maximum likehood estimation (MLE) menurut Ghozali (2015) maximum likehood estimation merupakan 100-200 sampel.

Peneliti kali ini menggunakan kuesioner yang disebarkan kepada responden secara online menggunakan Google forms. Kuesioner dibuat berdasarkan penelitian dengan berisi pertanyaan yang dapat digunakan untuk menggali informasi dari pengguna OVO.

Teknik pengambilan sampel yang peneliti gunakan untuk penelitian ini menggunakan nonprobability sampling. Menurut Juliansyah (2013) nonprobability sampling adalah sebuah teknik pengambilan sampel dimana setiap anggota populasi tidak memiliki peluang yang sama sebagai sampel. Teknik yang peneliti gunakan dalam nonprobability sampling ini menggunakan purposive sampling. Purposive sampling adalah metode penetapan responden yang dijadikan sampel berdasarkan kriteria-kriteria yang peneliti bentuk. Kriteria sampel penelitian ini ditetapkan sebagai berikut:

1. Pengguna e-wallet OVO yang berusia minimal 19 tahun

2. Pengguna berdomisili di Provinsi Jawa Timur

3. Menggunakan e-wallet OVO minimal 3 kali dalam 2 bulan terakhir

Dalam penelitian ini peneliti menggunakan dua analisis yaitu analisis deskriptif dan analisis infrensial sehingga dapat untuk menggambarkan kondisi lapangan dari pengguna OVO. Tujuan dari analisis deskriptif sendiri adalah untuk mengetahui gambaran penyebaran data sampel atau populasi berdasar Variabel manfaat yang dirasakan, keunggulan relatif pengaruh sosial, persepsi risiko, biaya, niat mengadopsi dan adopsi OVO.

Pada penelitian ini menggunakan teknik pengolahan data dengan suatu bentuk persamaan yang menunjukan arah pengaruh variabel eksogen (X) terhadap variabel endogen $(\mathrm{Y})$, dengan adanya kosntruk indicator atau dapat disebut menggunakan analisis PLS. Software WARP 
PLS digunakan sebagai alat analisis agar mendapatkan hasil yang lebih terarah. Dalam analisis PLS penulis menggunakan program WarpPLS dengan metode analisis Warp PLS regression, Warp PLS Regression, PLS Regression dan roboust path analysis. Pada penelitian ini akan menggunakan WarpPLS regression karena ini tidak mengharuskan sampel dalam jumlah besar.

\section{HASIL DAN PEMBAHASAN}

Peneliti menyebarkan kuesioner menggunakan Google Form kepada calon responden melalui media online seperti Whatsapp, Facebook, Instagram. Survey penelitian ini dilakukan mulai bulan Mei 2021 sampai bulan juni 2021. Kuesioner dari 130 responden yang terdiri dari 57 orang responeden laki-laki dan 73 orang responden perempuan, dimana mayoritas responden berusia antara 25 tahun hingga 29 tahun sebanyak 72 orang $(55,4 \%)$, berpendidikan Sarjana (S1) sebanyak 89 orang $(68,5 \%)$, pekerjaan pegawai swasta sebanyak 53 orang (40,8\%), telah menggunakan layanan OVO dalam jangka waktu lebih dari 2 tahun yaitu sejumlah 61 responden atau 46,9\%, dan mayoritas responden menggunakan OVO sebanyak 3 kali dalam 2 bulan terakhir sejumlah 60 orang responden $(46,2 \%)$.

Analisa data dengan Partial Least Squares (PLS) yang menggunakan sofware Warp-PLS versi 6.0 dilakukan dengan menilai outer model dan inner model. Outer model dilakukan untuk menilai validitas dan reliabilitas model atau menyatakan hubungan kausalitas antara indikator dengan variabel penelitian. Sedangkan inner model bertujuan untuk memprediksi hubungan antar variabel laten, dan melihat uji pengaruh dengan melihat nilai $\mathrm{T}$ statistic.

Berdasar tabel 1 menunjukan bahwa hasil pengujian validitas untuk semua pernyataan pada variabel bebas maupun variabel terikat menunjukan hasil yang valid atau memenuhi kriteria yaitu p signifikan ( $p$ $<$ 0,005). Hasil tabel menunjukan bahwa nilai composite reliability manfaat yang dirasakan memiliki reliabilitas sebesar 0,851, keunggulan relatif memiliki nilai composite reliability sebesar 0,884 , variabel pengaruh sosial memiliki nilai composite reliability sebesar 0,898, variabel persepsi risiko memiliki nilai composite reliability sebesar 0,896, variabel biaya memiliki nilai composite reliability sebesar 0,951, variabel niat mengadopsi memiliki nilai composite reliability sebesar 0,864, variabel adopsi OVO memiliki nilai composite reliability sebesar 0,941. Maka keakurasian dari data diatas sudah dapat dikatakan baik karena nilai dari suatu composite reliability dianggap baik jika nilainya $>0,70$ dan masing-masing variabel sudah berada di atas nilai minimum $(>0,7)$. 
Perhitungan dari composite reliability tersebut didukung juga oleh besarnya hasil perhitungan cronbach alpha (CA) dimana $\alpha$ pada manfaat yang dirasakan sebesar 0,766, nilai $\alpha$ pada keunggulan relatif sebesar 0,802 , nilai $\alpha$ pada pengaruh sosial sebesar 0,830, nilai $\alpha$ pada persepsi risiko sebesar 0,844 , nilai $\alpha$ pada biaya sebesar 0,932 , nilai $\alpha$ pada niat mengadopsi sebesar 0,764, dan pada adopsi OVO memiliki nilai $\alpha$ sebesar 0,875. Hasil tersebut menunjukkan bahwa semua variabel telah melampaui syarat reliabilitas yang baik yang nilai cronbach's alpha diatas 0,60, sehingga dapat dikatakan sudah reliabel dan memenuhi kriteria.

Berdasarkan tabel 1 AVE pada variabel laten manfaat yang dirasakan sebesar 0,598 $(>0,5)$, keunggulan relatif sebesar 0,718 (> 0,5), pengaruh sosial memiliki nilai AVE sebesar 0,748 (> 0,5), variabel persepsi risiko sebesar 0,683 $(>0,5)$, variabel biaya memiliki nilai AVE sebesar 0,830 (>0,5), variabel niat mengadopsi $0,680(>0,5)$ dan pada variabel adopsi OVO memiliki nilai AVE sebesar 0,889 (>0,5). Hasil tersebut memperlihatkan bahwa nilai AVE masingmasing indikator dapat dinyatakan valid atau memenuhi kriteria yaitu nilainya $>0.5$.

Tabel 1

Outer Model

\begin{tabular}{|c|c|c|c|c|}
\hline Variabel & $\begin{array}{c}\text { Kode } \\
\text { Variabel }\end{array}$ & Loading Factor & $\begin{array}{c}\text { Composite reliability } \\
\text { coefficients }\end{array}$ & $A V E$ \\
\hline \multirow{4}{*}{$\begin{array}{l}\text { Manfaat Yang } \\
\text { Dirasakan }\end{array}$} & MYD1 & 0.819 & \multirow{4}{*}{0.851} & \multirow{4}{*}{0.589} \\
\hline & MYD2 & 0.779 & & \\
\hline & MYD3 & 0.682 & & \\
\hline & MYD4 & 0.785 & & \\
\hline \multirow{3}{*}{$\begin{array}{l}\text { Keunggulan } \\
\text { Relatif }\end{array}$} & KR1 & 0.878 & \multirow{3}{*}{0.884} & \multirow{3}{*}{0.718} \\
\hline & KR2 & 0.871 & & \\
\hline & KR3 & 0.790 & & \\
\hline \multirow{3}{*}{ Pengaruh Sosial } & PS1 & 0.873 & \multirow{3}{*}{0.898} & \multirow{3}{*}{0.746} \\
\hline & PS2 & 0.823 & & \\
\hline & PS3 & 0.894 & & \\
\hline \multirow{4}{*}{ Persepsi Risiko } & PR1 & 0.836 & \multirow{4}{*}{0.896} & \multirow{4}{*}{0.683} \\
\hline & PR2 & 0.872 & & \\
\hline & PR3 & 0.855 & & \\
\hline & PR4 & 0.735 & & \\
\hline \multirow{4}{*}{ Biaya } & $\mathrm{BI} 1$ & 0.873 & \multirow{4}{*}{0.951} & \multirow{4}{*}{0.830} \\
\hline & $\mathrm{BI} 2$ & 0.925 & & \\
\hline & BI3 & 0.937 & & \\
\hline & BI4 & 0.909 & & \\
\hline \multirow{3}{*}{ Niat Mengadopsi } & NP1 & 0.841 & \multirow{3}{*}{0.864} & \multirow{3}{*}{0.680} \\
\hline & NP2 & 0.858 & & \\
\hline & NP3 & 0.772 & & \\
\hline \multirow{2}{*}{ Adopsi OVO } & $\mathrm{AD} 1$ & 0.943 & \multirow{2}{*}{0.941} & \multirow{2}{*}{0.889} \\
\hline & AD2 & 0.943 & & \\
\hline
\end{tabular}

Sumber: Data diolah, 2021 
Tabel 2

Hasil Uji Hipotesis

\begin{tabular}{lcll}
\multicolumn{1}{c}{ Variabel } & $\begin{array}{c}\text { Path } \\
\text { Coefficients }\end{array}$ & P Value & \multicolumn{1}{c}{ Keterangan } \\
Manfaat Yang Dirasakan $\rightarrow$ Niat & 0.378 & $\mathrm{P}=<0.001$ & Signifikan \\
Mengadopsi & 0.268 & $\mathrm{P}=<0.001$ & Signifikan \\
Keunggulan Relatif $\rightarrow$ Niat Mengadopsi & 0.114 & $\mathrm{P}=0.092$ & Tidak Signifikan \\
Pengaruh Sosial $\rightarrow$ Niat Mengadopsi & -0.090 & $\mathrm{P}=0.149$ & Tidak Signifikan \\
Persepsi Risiko $\rightarrow$ Niat Mengadopsi & -0.026 & $\mathrm{P}=0.384$ & Tidak Signifikan \\
Biaya $\rightarrow$ Niat Mengadopsi & 0.706 & $\mathrm{P}=<0.001$ & Signifikan \\
Niat Mengadopsi $\rightarrow$ Adopsi OVO & & &
\end{tabular}

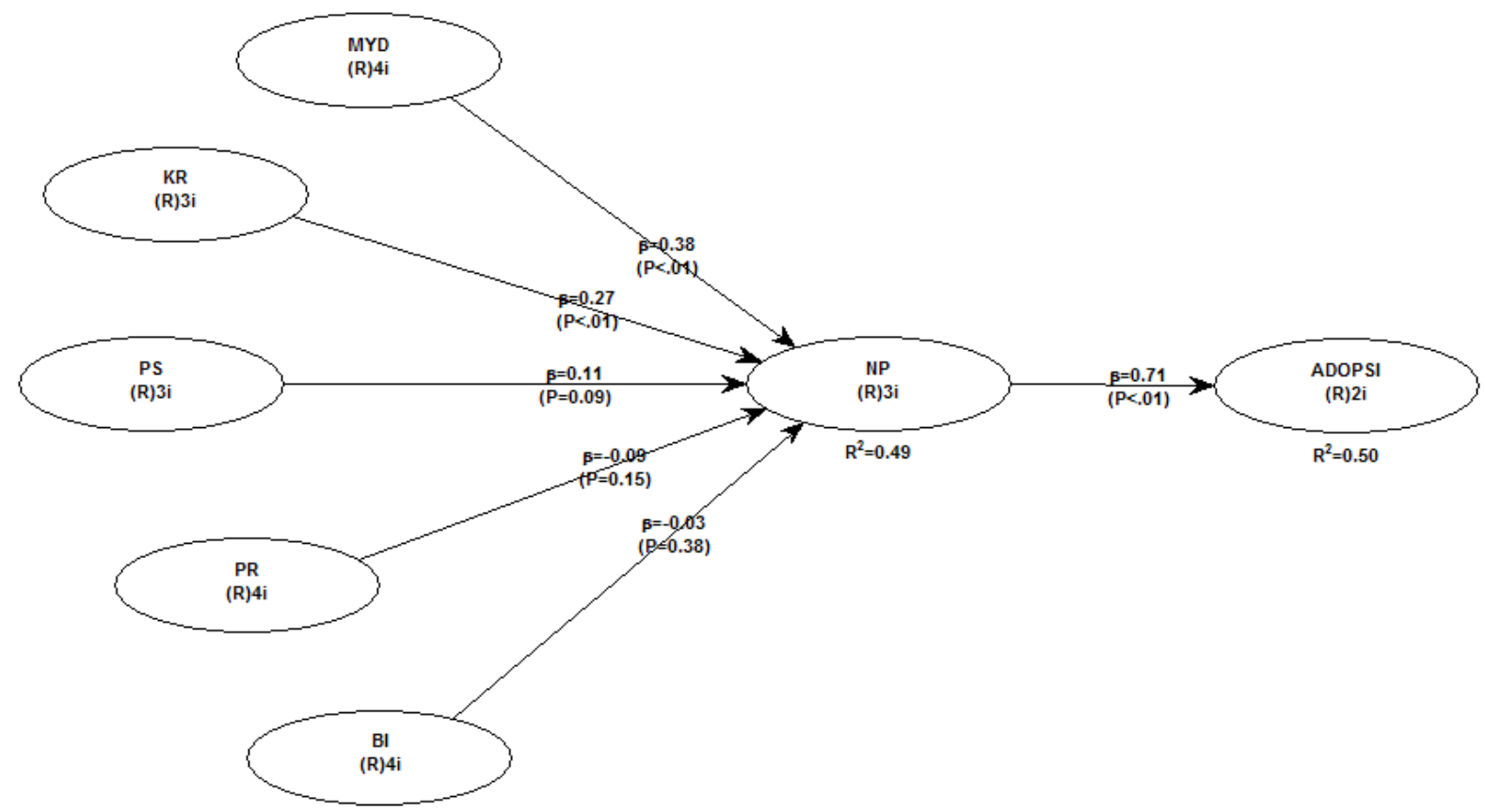

Sumber : Data diolah, 2021

Gambar 2

Koefisien Jalur

Berdasarkan hasil analisa data dan interpretasi hasil analisis program Warp$P L S$, maka penelitian ini menunjukkan hasil sebagai berikut

1. Hasil analisa data menunjukan bahwa hipotesis pertama dalam penelitian ini terbukti, yaitu manfaat yang dirasakan berpengaruh signifikan positif terhadap niat mengadopsi pada OVO. Sehingga dapat diartikan variabel manfaat yang dirasakan semakin tinggi maka akan semakin meningkatkan niat mengadopsi pada OVO. Manfaat yang dirasakan juga dapat diartikan sebagai faktor yang mempengaruhi atau menjadi pendorang 
terhadap niat mengadopsi pengguna OVO.

Hasil dari hipotesis pertama sejalan dengan penelitian dari Charles Makanyeza (2017) manfaat yang dirasakan yang berpengaruh signifikan positif terhadap niat mengadopsi pada mobile banking. Hasil juga sesuai dengan penelitian yang telah dilakukan oleh Ali Abdallah Alalwan Yogesh K. Dwivedi Nripendra P. P. Rana Michael D. Williams (2016) yang memperoleh hasil bahwa manfaat yang dirasakan adalah faktor kunci dari nasabah untuk mengubah perilaku nasabah terhadap mobile banking di Yordania. Pada hasil penelitian dari Wang dan Dai, (2020) manfaat yang dirasakan mempengaruhi langsung niat mengadopsi offline mobile payment, selain itu dalam penelitian ini dinyatakan jika manfaat yang dirasakan didefinisikan sebagai sejauh mana konsumen percaya bahwa menggunakan layanan OVO akan meningkatkan kinerja keuangannya. Sehingga dengan diterimanya hipotesis ini maka semakin tinggi manfaat yang dirasakan oleh para pengguna layanan maka niat menggadopsi juga akan semakin meningkat untuk menggunakan layanan tersebut.

2. Hasil analisa data menunjukan bahwa hipotesis ke-2 dalam penelitian ini terbukti, yaitu keunggulan relatif berpengaruh signifikan positif terhadap niat mengadopsi pada OVO. Sehingga semakin meningkatnya keunggulan relatif juga akan berpengaruh terhadap meningkatnya niat mengadopsi pada OVO dan dapat diartikan sebagai variabel keunggulan relatif mempengaruhi atau menjadi pendorang terhadap niat mengadopsi pengguna OVO.

Hasil penelitian ini sejalan dengan hasil penelitian yang telah dilakukan oleh Makanyeza (2017) yang menunjukkan hasil bahwa keunggulan relatif berpengaruh signifikan terhadap niat mengadopsi dalam penggunaan mobile banking. Keunggulan Relatif merupakan sejauh mana individu merasakan kemudahan serta manfaat dari inovasi suatu layanan yang digunakan sebelumnya. Keunggulan relatif adalah sebagai derajat dimana seorang pengguna $e$-wallet memandang suatu inovasi dari layanan OVO sebagai keunggulan kelebihan dibanding sistem yang sudah ada sebelumnya yaitu pembayaran manual. Keunggulan relatif yang semakin bertambah menyebabkan pula peningkatan pada niat mengadopsi layanan OVO.

3. Hasil analisa data menunjukkan bahwa pada hipotesis yang ke-3 (tiga) atau H3 pada penelitian ini ditolak. Hasil path coefficients menunjukan variabel pengaruh sosial terhadap niat 
mengadopsi memiliki nilai sebesar 0.114 hal ini menunjukan bahwa variabel terdapat pengaruh positif. Namun nilai $p$ value $(\mathrm{P}=0.092)$ atau lebih dari dari 0,05 sehingga menunjukan hasil yang tidak signifikan. Maka dapat disimpulkan bahwa pengaruh sosial tidak berpengaruh signifikan positif terhadap niat mengadopsi pada OVO.

Hasil penelitian ini tidak konsisten dengan penelitian yang dilakukan oleh Makanyeza (2017) maupun De Luna et al., 2019, yang menunjukkan bahwa pengaruh sosial berpengaruh signifikan positif terhadap niat mengadopsi. Menurut hasil penelitian dari De Sena (2016) pengaruh sosial berpengaruh signifikan positif terhadap niat mengadopsi mobile payment. Menurut Wang dan Dai, (2020) pengaruh sosial adalah sejauh mana pengguna individu mendapatkan saran tentang pentingnya penggunakan inovasi. Saat ada teknologi/layanan baru muncul ini membuat individu tersebut masih ragu untuk menggunakannya dan akan berinteraksi kepada orang yang sudah menggunaknya sebelum membuat keputusan. Perbedaan hasil penelitian dengan sebagian besar penelitian tedahulu dikarenakan mayoritas responden dalam penelitian ini berusia antara 25 sampai dengan 29 tahun dimana pada usia tersebut merupakan generasi milenial yang sangat memahami teknologi dengan baik sehingga tidak dipengaruhi atau tidak memerlukan rekomendasi orang lain dari lingkungan sosial untuk menggunakan layanan OVO.

4. Hasil analisa data menunjukkan bahwa pada hipotesis yang ke-4 atau H4 pada penelitian ini ditolak. Hasil path coefficients menunjukan variabel persepsi risiko terhadap niat mengadopsi memiliki nilai sebesar -0.090 hal ini menunjukan bahwa variabel persepsi risiko terdapat pengaruh negatif dan nilai $p$ value $(\mathrm{P}=0.149)$ atau lebih dari dari 0,05 sehingga menunjukan hasil yang tidak signifikan. Maka dapat disimpulkan bahwa persepsi risiko tidak berpengaruh signifikan negatif terhadap niat mengadopsi pada OVO.

Hasil penelitian ini tidak konsisten dengan penelitian yang dilakukan oleh De Luna et al., 2019 dimana persepsi risiko berpengaruh signifikan negatif terhadap niat mengadopsi mobile wallet. Menurut hasil penelitian dari Makanyeza (2017) menunjukan persepsi risiko berpengaruh negatif terhadap niat mengadopsi mobile banking. Menurut hasil penelitian dari dari Hongxia et al., 2011 persepsi risiko berpengaruh negatif terhadap niat menggunakan mobile payment. Pada hasil penelitian De Sena et al., 2016 menunjukan bahwa persepsi risiko berpengaruh signifikan negatif terhadap 
niat mengadopsi mobile payment. Menurut hasil penelitian Alalwan et al., 2016 persepsi risiko berpengaruh signifikan negatif terhadap niat mengadopsi mobile banking. Sebagian besar hasil penelitian tidak sesuai dengan hipotesis penelitian ini dikarenakan oleh responden percaya akan adanya risiko yang mungkin didapatkannya, dan hasil ini juga sejalan dengan data pada analisis deskriptif jawaban responden terhadap variabel persepsi risiko menunjukan bahwa responden netral dengan adanya risiko yang mungkin didapat pelanggan saat melakukan pembayaran melalui OVO. Responden memilih netral dikarenakan responden tersebut menyadari adanya risiko tersebut tetapi di sisi lain responden juga membutuhkan untuk menggunakan layanan ini.

5. Hasil analisa data menunjukkan bahwa pada hipotesis yang ke lima atau H5 pada penelitian ini ditolak. Hasil path coefficients menunjukan variabel biaya terhadap niat mengadopsi memiliki nilai sebesar -0.026 hal ini menunjukan bahwa variabel biaya terdapat pengaruh negatif dan nilai $p$ value $(\mathrm{P}=0.384)$ atau lebih dari dari 0,05 sehingga menunjukan hasil yang tidak signifikan. Maka dapat disimpulkan bahwa biaya tidak berpengaruh signifikan negatif terhadap niat mengadopsi pada OVO.
Hasil hipotesis ini tidak sejalan dengan hasil penelitian dari dari Hongxia et al., 2011 dimana variabel biaya perpengaruh signifikan negatif terhadap niat mengadopsi pada mobile payment.

6. Hasil analisa data menunjukkan bahwa hipotesis ke-6 pada penelitian ini terbukti, yaitu niat mengadopsi berpengaruh signifikan positif terhadap adopsi OVO. Niat mengadopsi didefinisikan sebagai perasaan positif atau negatif seorang pengguna $e$-wallet terhadap niatnya dalam memakai layanan OVO sehingga disimpulkan bahwa variabel niat mengadopsi menjadi pendorong konsumen untuk mengadopsi atau menggunakan layanan secara penuh.

Sejalan dengan hasil penelitian yang telah dilakukan oleh Makanyeza (2017); Alalwan et al., 2016; dan Wang dan Dai, (2020). Menurut Makanyeza (2017), perilaku adalah evaluasi, perasaan dan kecenderungan seseorang yang relatif konsisten terhadap suatu objek dan gagasan. Perilaku menempatkan seseorang kedalam satu pikiran menyukai atau tidak menyukai obyek dan ide tertentu hal ini bahkan dapat bergerak mendekati atau menjauhi sesuatu. Peran faktor niat mengadopsi merupakan suatu hal yang sangat penting bagi seorang pengguna suatu layanan baik yang hendak memakai atau 
untuk terus menggunakan suatu layanan. Peningkatan niat mengadopsi ditandai dengan munculnya niat seseorang untuk menggunakan layanan OVO secara terus menerus atau menggunakan sepenuhnya.

\section{KESIMPULAN}

Kesimpulan yang diperoleh berdasarkan analisis data dan pengujian hipotesis, maka dapat disimpulkan bahwa :

1. Berdasarkan hasil pengujian hipotesis menunjukkan bahwa manfaat yang dirasakan oleh konsumen mampu memberikan kontribusi yang tinggi dalam membentuk niat konsumen untuk mengadopsi OVO. Hal ini dapat dijelaskan bahwa semakin tinggi manfaat yang dirasakan akan berpengaruh pada semakin meningkatnya niat mengadopsi pada OVO. Sehingga dapat disimpulkan bahwa hipotesis pertama (H1) diterima.

2. Berdasarkan hasil pengujian hipotesis menunjukkan bahwa keunggulan relatif sanggup memberikan kontribusi yang cukup tinggi dalam membentuk niat konsumen untuk mengadopsi layanan dompet digital OVO. Dalam hipotesis ini dapat dijelaskan bahwa semakin tinggi keunggulan relatif akan berpengaruh pada semakin meningkatnya niat mengadopsi pada OVO. Sehingga dapat disimpulkan hipotesis (H2) diterima.
3. Berdasarkan hasil pengujian hipotesis menunjukkan bahwa pengaruh sosial tidak memiliki peran serta dalam membentuk niat konsumen untuk mengadopsi layanan e-wallet OVO. Hal ini dapat disimpulkan bahwa pengaruh sosial tidak mempengaruhi niat konsumen untuk mengadopsi layanan OVO. Sehingga hipotesis ke tiga (H3) ditolak.

4. Berdasarkan hasil pengujian hipotesis menunjukkan bahwa persepsi risiko tidak menghambat atau bukan suatu hal yang dikhawatirkan oleh pengguna dalam membentuk niat konsumen untuk mengadopsi layanan OVO. Hal ini dapat disimpulkan bahwa persepsi risiko tidak berpengaruh pada niat mengadopsi pada OVO. Sehingga hipotesis (H4) ini ditolak.

5. Berdasarkan hasil pengujian hipotesis menunjukkan bahwa biaya tidak menghambat atau bukan suatu hal yang dikhawatirkan oleh pengguna dalam membentuk niat konsumen untuk mengadopsi layanan OVO. Hal ini dapat disimpulkan bahwa biaya tidak berpengaruh pada niat mengadopsi pada OVO. Sehingga hipotesis lima (H5) ditolak.

6. Berdasarkan hasil pengujian hipotesis menunjukkan bahwa niat mengadopsi memberikan kontribusi yang tinggi dalam proses adopsi OVO. Dalam hipotesis ini menunjukkan bahwa semakin tinggi niat 
mengadopsi akan berpengaruh pada semakin meningkatnya adopsi OVO. Sehingga dapat disimpulkan bahwa hipotesis ke enam (H6) diterima.

\section{IMPLIKASI PENELITIAN}

Hasil dari penelitian ini dapat menjadi landasan tambahan dan rujukan dalam pengambilan keputusan manajerial oleh PT. Visionet Internasional selaku pemilik layanan OVO dalam peningkatan kualitas terkait dengan pengaruh manfaat yang dirasakan, keunggulan relatif, pengaruh sosial, persepsi risiko, biaya dan niat mengadopsi terhadap adopsi OVO di Provinsi Jawa Timur.

Memperluas kerja sama dengan merchant-merchant baru dan menambah fitur-fitur baru agar dapat digunakan lebih mudah digunakan dan dapat meningkatkan kinerja pengguna layanan. Dalam penelitian ini hasil dari variabel manfaat yang dirasakan menunjukan bahwa responden sudah sangat puas dengan layanan OVO sehingga alangkah baiknya OVO dapat menjaga dan meningkatkan layanannya.

Memperkaya fitur yang dapat dimanfaatkan pengguna dalam mengelola dan mengontrol keuangannya. Fitur history di OVO yang sudah ada tetapi belum dimanfaatkan oleh pengguna dengan baik. Mayoritas responden setuju jika metode pembayaran menggunakan layanan OVO merasakan kemudahan dan manfaatnya dibanding metode pembayaran tunai.

Perlunya adanya program pemberian reward bagi pengguna layanan yang merekomendasikan OVO kepada orangorang disekitarnya, dikarenakan hasil dari tanggapan responden yang setuju mengenai pengaruh sosial atau pengaruh dari orang sekitarnya untuk menggunakan layanan OVO tetapi tidak signifikan. Program seperti ini sangat penting dan dapat mendorong word of mouth sehingga saat pengguna layanan merekomendasikan OVO maka akan mendapat reward.

OVO perlu memberikan kepastian kepada pengguna bahwa layanan OVO aman dari kemungkinan terjadinya risikorisiko seperti kesalahan fungsi dan keamanan privasi. Respon seharusnya lebih ditingkatkan jika ada komplain dari para pengguna. Meningkatkan keamanan data dan keamanan dalam bertransaksi juga harus dilakukan oleh OVO dikarenakan masih terjadi masalah dalam bocornya privasi dan masalah dalam bertransaksi seperti hilangnya saldo pengguna layanan.

\section{ACKNOWLEDGEMENT}

Penulis mengucapkan terimakasih kepada dosen pembimbing atas masukannya dan kepada semua pihak yang membantu sehingga penelitian ini dapet terselesaikan. 


\section{DAFTAR PUSTAKA}

Alalwan, A. A., Dwivedi, Y. K., Rana, N. P., \& Williams, M. D. (2016). Consumer adoption of mobile banking in Jordan: Examining the role of usefulness, ease of use, perceived risk and self-efficacy. Journal of Enterprise Information Management, 29(1), pp.118-139.

Bashir, I., \& Madhavaiah, C. (2015). Consumer attitude and behavioural intention towards Internet banking adoption in India. Journal of Indian Business Research, 7(1), pp.67-102.

Daştan, İ., \& Gürler, C. (2016). Factors affecting the adoption of mobile payment systems: An empirical analysis. EMAJ: Emerging Markets Journal, 6(1), 17-24.

De Luna, I. R., Liébana-Cabanillas, F., Sánchez-Fernández, J., \& Munoz-Leiva, F. (2019). Mobile payment is not all the same: The adoption of mobile payment systems depending on the technology applied. Technological Forecasting and Social Change, 146, 931-944.

De Sena Abrahão, R., Moriguchi, S. N., \& Andrade, D. F. (2016). Intention of adoption of mobile payment: An analysis in the light of the Unified Theory of Acceptance and Use of Technology (UTAUT). RAI Revista de Administração e Inovação, 13(3), 221-230.

Ghozali, I. and Latan, H., 2015. Partial least squares: Konsep, teknik dan aplikasi menggunakan program SmartPLS 3.0 untuk penelitian empiris. Semarang: Badan Penerbit UNDIP.

Halttunen, V. (2016). Consumer behavior in digital era: general aspects and findings of empirical studies on digital music with a retrospective discussion. Jyväskylä studies in computing, (235).

Hongxia, P., Xianhao, X. U., \& Weidan, L. I. U. (2011). Drivers and barriers in the acceptance of mobile payment in China. In 2011 International Conference on E-business and E-government (ICEE) (pp. 1-4). IEEE.

Juliansyah, N. (2013). Penelitian Ilmu Manajemen Tinjauan Filosofis dan Praktis. Prenadamedia: Jakarta.

Kotler, P., \& Armstrong, G. (2008). Prinsip-prinsip pemasaran jilid 1 edisi 12. Jakarta: Erlangga.

Madan, K., \& Yadav, R. (2016). Behavioural intention to adopt mobile wallet: a developing country perspective. Journal of Indian Business Research.

Makanyeza, C. (2017). Determinants of consumers' intention to adopt mobile banking services in Zimbabwe. International Journal of Bank Marketing.

Kuncoro, M. (2013). Metode Riset Untuk Bisnis \& Ekonomi, Edisi Keempat. Jakarta: Erlangga, 2, 14.

Phuah, K. T., TingJL, J. L., \& Wong, K. K. S. (2018). Understanding customer intention to use mobile payment services in Nanjing, China. International Journal of Community Development and Management Studies, 2, 049-060.

Punwatkar, S., \& Verghese, M. (2018). Adaptation of e-Wallet Payment: An Empirical Study on Consumers' Adoption Behavior in Central India. International Journal of Advanced in Management, Technology and Engineering Sciences, 8(3), 1147-1156. 
Schiffman, L., \& Kanuk, L. L. (2008). Perilaku konsumen edisi ketujuh. Jakarta: Indeks.

Shaikh, A. A., \& Karjaluoto, H. (2015). Mobile banking adoption: A literature review. Telematics and informatics, 32(1), 129-142.

Suryani, Tatik. (2012), Perilaku Konsumen: Implikasinya pada Strategi Pemasaran. Edisi 1. Yogyakarta: Graha Ilmu.

Wang, L., \& Dai, X. (2020). Exploring factors affecting the adoption of mobile payment at physical stores. International Journal of Mobile Communications, 18(1), 67-82.

\section{Situs :}

https://blog.apjii.or.id/index.php/2020/11/09/siaran-pers-pengguna-internet-indonesiahampir-tembus-200-juta-di-2019-q2-2020/

https://iprice.co.id/trend/insights/e-wallet-terbaik-di-indonesia/

https://www.bi.go.id/id/peraturan/sistem-pembayaran/Pages/pbi_184016.aspx

https://www.nielsen.com/id/id/press-releases/2020/konsumen-digital-menunjukkanpertumbuhan-tren-positif 